\title{
What Is This Reticulated, Erythematous Eruption on a Woman's Buttocks?
}

Iris Hunt, MS' - Christina T. Hanos, $\mathrm{BS}^{2}$ - Tara Paolini, $\mathrm{MD}^{3}$ - Thomas N. Helm, MD

A 44-year-old woman presented to our clinic with gradually developing skin lesions on her buttocks. She reported that the areas would occasionally become sensitive, irritated, and eroded, with the condition worsening over the last few years (Figure).

The patient had a history of chronic pain secondary to peripheral neuropathy in her left gluteal region, which was relieved with frequent use of a heating pad. Biopsy of the tissue revealed an atrophic epidermis, keratinocyte atypia, and melanophages; there was no evidence of inflammation of the blood vessel walls.

Which of the following is the most likely diagnosis?
A. Erythema ab igne
B. Livedo reticularis
C. Polyarteritis nodosa
D. Mycosis fungoides

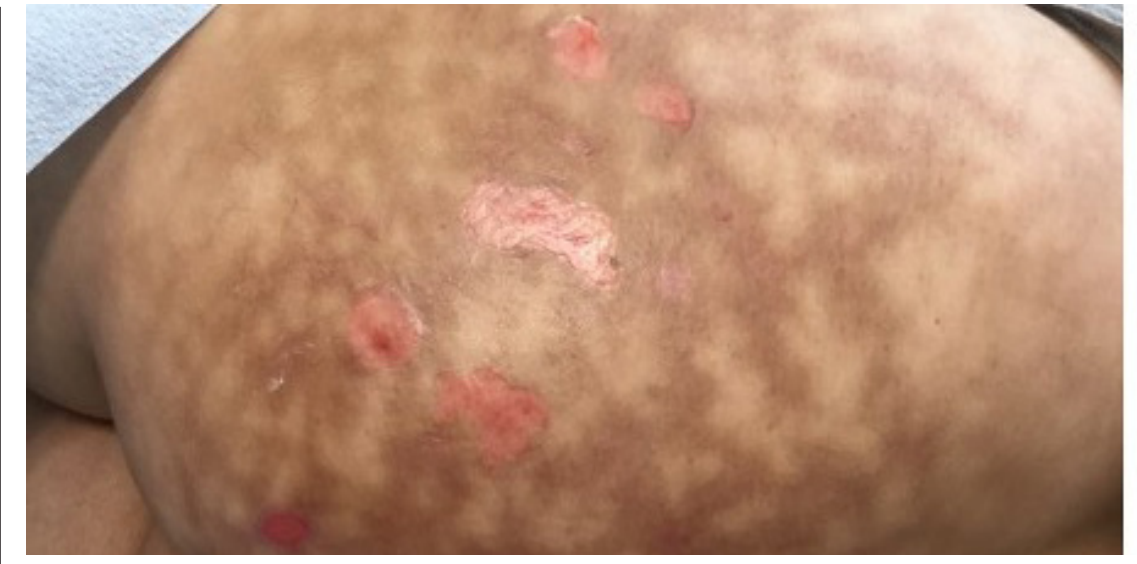

Figure. The skin lesion on our patient's buttocks would occasionally become sensitive, irritated, and eroded.

\section{Correct answer: A. Erythema ab igne}

Erythema ab igne is a cutaneous dermatosis characterized by a pattern of reticular erythema, telangiectasias, and hyperpigmentation ${ }^{1-3}$ It develops because of chronic and repeated exposure of the skin to low levels of infrared radiation. Current heat sources that cause erythema ab igne include heating pads,

\section{IAFFILIATIONS: \\ 'Louisiana State University School of Medicine, New Orleans, Louisiana \\ ${ }^{2}$ Albany Medical College, Albany, New York \\ ${ }^{3}$ Jacobs School of Medicine, Buffalo, New York}

\section{CITATION:}

Hunt I, Hanos CT, Paolini T, Helm TN. What is this reticulated, erythematous eruption on a woman's buttocks? Consultant. Published online January 21, 2022. doi:10.25270/con.2022.01.00004

Received September 3, 2021. Accepted September 24, 2021.

\section{DISCLOSURES:}

The authors report no relevant financial relationships.

\section{CORRESPONDENCE:}

Iris Hunt, MS, Louisiana State University School of Medicine, 1901 Perdido Street, New Orleans, LA 70112 (ihunt@lsuhsc.edu) car heaters, electric space heaters, hot water bottles, and laptops. ${ }^{4,5}$ Originally described in people who sat near open flames or used hot stoves, more recently erythema ab igne has been found among those with chronic pain who thereby use heat sources for symptomatic relief. Although this lesion typically presents asymptomatically, it has been also associated with causing sensations of pain, burning, and pruritus in affected individuals. Histopathology of erythema ab igne typically reveals epidermal atrophy, dermal elastosis, melanophages, histiocyte and keratinocyte atypia, and deposition of melanin and hemosiderin. ${ }^{6}$ Telangiectatic blood vessels are seen as dilated vessels in the superficial papillary dermal plexus throughout the lesion.

Treatment of erythema ab igne involves removal of the offending heat agent; mild cases usually resolve over the course of months, while more advanced cases can persist for years or remain permanently. ${ }^{6}$ Although the lesion generally has a favorable prognosis, long-standing erythema 
ab igne increases the risk for cutaneous malignancies such as actinic keratosis and squamous cell, basal cell, and merkel cell carcinomas. ${ }^{5,7}$ The differential diagnosis of erythema ab igne is broad. Reticular lesions are associated with connective tissue disease, hypercoagulable states secondary to antiphospholipid antibodies, use of certain medications such as amantadine and memantine, ${ }^{8}$ as well as complex regional pain syndrome (ie, reflex sympathetic dystrophy). ${ }^{8,9}$

The clinical image in this case is typical. The keratinocyte atypia and melanophages noted do not occur in livedo reticularis. Polyarteritis nodosa is a vasculitis of medium-sized blood vessels and would therefore be associated with inflammation of vessel walls and other features of vasculitis. ${ }^{8}$ Patients are typically very ill, and the lesion does not develop gradually and slowly as described by our patient. Mycosis fungoides is a cutaneous T-cell lymphoma that can be associated with unusual skin lesions.10 In this situation, however, a biopsy would reveal atypical lymphocytes in the epidermis that were not seen in our patient. Additionally, patients with polyarteritis nodosa and mycosis fungoides tend to have systemic symptoms such as weight loss, fever, and malaise..$^{10,11}$

Treatment of erythema ab igne is supportive. Avoidance of further exposure to the offending heat source is standard management. Treatment with 5-fluoro- uracil, tretinoin, or laser therapy may aid in the reduction of visible deformation from the lesion. Importantly, because of the increased risk of skin cancer in the affected area, patients must be surveilled for the development of premalignant transformation, as this should prompt referral to a dermatologist and for a biopsy as indicated.

\section{References}

1. Brzezinski P, Ismail S, Chiriac A. Radiator-induced erythema ab igne in 8-year-old girl. Rev Chil Pediatr. 2014;85(2):239240. https://doi.org/10.4067/s037041062014000200015

2. Arnold AW, Itin PH. Laptop computer-induced erythema ab igne in a child and review of the literature. Pediatrics. 2010;126(5):e1227-e1230. https://doi. org/10.1542/peds.2010-1390

3. Dizdarevic A, Karim OA, Bygum A. A reddish brown reticulated hyperpigmented erythema on the abdomen of a girl. Erythema ab igne, also known as toasted skin syndrome, caused by a heating pad on the abdomen. Acta Derm Venereol. 2014;94(3):365-367. https://doi. org/10.2340/00015555-1722

4. Helm TN, Spigel GT, Helm KF. Erythema ab igne caused by a car heater. Cutis. 1997;59(2):81-82. https://europepmc.org/ article/med/9040977

5. Miller K, Hunt R, Chu J, Meehan S, Stein J. Erythema ab igne. Dermatol Online J. 2011;17(10):28. https://doi.org/10.5070/
D347z4v01z

6. Wells A, Desai A, Rudnick EW, Motaparthi $K$. Erythema ab igne with features resembling keratosis lichenoides chronica. J Cutan Pathol. 2021;48(1):151-153. https://doi. org/10.1111/cup.13885

7. Daneshvar E, Seraji S, Kamyab-Hesari K, Ehsani AH, Hanifnia AR, Razavi Z. Basal cell carcinoma associated with erythema ab igne. Dermatol Online J. 2020;26(4):13030/ qt3kz985b4. https://doi.org/10.5070/ D3264048367

8. Adya KA, Inamadar AC, Palit A. Reticulate dermatoses. Indian J Dermatol. 2014;59(1):314. https://doi.org/10.4103/00195154.123480

9. Marinus J, Moseley GL, Birklein F, et al. Clinical features and pathophysiology of complex regional pain syndrome. Lancet Neurol. 2011;10(7):637-648. https://doi. org/10.1016/s1474-4422(11)70106-5

10. Bagot M, Stadler R. Cutaneous lymphoma. In: Kang S, Amagai M, Bruckner AL, et al, eds. Fitzpatrick's Dermatology. 9th ed. McGraw-Hill Education; 2019. https:// accessmedicine.mhmedical.com/content. aspx ?bookid $=2570 \&$ sectionid $=210435990$

11. Merkel PA, Monach PA. Systemic necrotizing arteritis. In: Kang $\mathrm{S}$, Amagai $\mathrm{M}$, Bruckner AL, et al, eds. Fitzpatrick's Dermatology. 9th ed. McGraw-Hill Education; 2019. https://accessmedicine.mhmedical. com/content.aspx?bookid=2570\&sectionid $=210428829$ 